\title{
Allelopathic effect on a nutrient-limited phytoplankton species
}

\author{
Giovana O. Fistarol ${ }^{1,2, *}$, Catherine Legrand ${ }^{1}$, Edna Granéli $^{1}$ \\ ${ }^{1}$ Marine Sciences Division, Department of Biology and Environmental Science, University of Kalmar, 39231 Kalmar, Sweden \\ ${ }^{2}$ Present address: LabTox, Dept. Eng. Sanitaria e Ambiental, Centro Tecnologica, UFSC, Campus Trindade, Florianopolis, \\ SC, CEP 88040-900, Brazil
}

\begin{abstract}
For aquatic systems, studies on allelopathic interactions among phytoplankton have increased over recent years, with the main focus on the role of the donor organism. In this study, we report on the response of a target organism to allelochemicals and whether this response was affected by stress conditions (nutrient limitation). We exposed the diatom Thalassiosira weissflogii, grown under different nitrogen $(\mathrm{N})$ and phosphorus $(\mathrm{P})$ conditions $(\mathrm{NP},-\mathrm{N}$, or $-\mathrm{P})$, to single or daily additions of a cell-free filtrate of Prymnesium parvum (grown with no nutrient limitation). When we exposed T. weissflogii to a single addition of filtrate, all 3 treatments were inhibited by $P$. parvum. However, T. weissflogii NP was the most resistant, while T. weissflogii-N showed the highest sensitivity to $P$. parvum filtrate, followed by $T$. weissflogii-P. When $T$. weissflogii was exposed to daily additions of $P$. parvum, the degree of inhibition of all $T$. weissflogii treatments was higher than when only 1 initial addition was made. In this case, even the treatment that had the highest resistance ( $T$. weissflogii NP) was not only inhibited by the filtrate, but also showed a decrease in cell numbers. Nevertheless, T. weissflogii-N was still more sensitive than the other treatments. Therefore, nutrient-limiting conditions may increase allelopathic effects, by making the target more susceptive to allelopathic compounds. Under these conditions, allelopathy may play a strong role in phytoplankton competition, especially in natural environments where the allelochemicals are continuously released and, thus, the target species do not have time to recover.
\end{abstract}

KEY WORDS: Allelopathy · Phytoplankton · Target organism · Nutrient limitation · Thalassiosira weissflogii · Prymnesium parvum

Resale or republication not permitted without written consent of the publisher

\section{INTRODUCTION}

Allelopathy is the study of 'any direct or indirect, harmful or beneficial effect of plants, protists (e.g. microalgae, ciliates), bacteria, or viruses on another through production of chemical compounds that are released into the environment' (modified from Rice 1984). It has been widely studied in terrestrial ecology, due to its economical importance for agriculture (Rizvi et al. 1992, Einhellig 1995). The fact that aquatic plants and algae probably have allelopathic properties has been proposed sporadically since Akehurst suggested the existence of non-nutritional interactions between phytoplankton mediated by organic compounds in 1931 (Maestrini \& Bonin 1981). However, it is only recently that more effort has been put into the study of allelopathy among phytoplankton in aquatic environments (Legrand et al. 2003), with most emphasis placed on understanding the role of the donor organisms and their effects. Little is known about the factors influencing the response of the target organisms.

However, because of the characteristics of the aquatic environment, both donor and target organism are under the influence of the same stress factors (e.g. nutrient limitation). Stress factors affect the donor species by, e.g., increasing the production of allelochemicals (Tang et al. 1995, Granéli \& Johansson 2003). It has also been suggested that stress could affect the target organism by making it more sensitive to allelochemicals (Einhellig 1995, Tang et al. 1995, Reigosa et 
al. 1999), although few studies have really tested this hypothesis (Einhellig 1996) and those that did only concentrated on higher plants.

Allelopathy is a form of interference competition, and, together with resource exploitation, it is used to explain patterns in plant competition dynamics (Rice 1984). Thus, factors that enhance the allelopathic effect may change the competitive balance towards allelopathic organisms. Since all plants and algae experience some kind of stress during growth, it is probable that the stress factors interact with allelopathy, thus changing the outcome of competition.

In the present study, we investigated if the response of target phytoplankton species, which were exposed to allelochemicals, is affected by nutrient limitation. The fact that the allelopathic effect may be lost some time after exposure due to the degradation of the causative compounds was taken into consideration. Therefore, we also tested the response of nutrient-limited target species when exposed to a single addition of filtrate or to daily additions, and compared the results. Daily filtrate additions may better mimic what occurs in the environment, since they simulate a continuous release of allelochemicals (Suikkanen et al. 2004). The diatom Thalassiosira weissflogii (KAC 32, Kalmar Algal Collection) was chosen as the target species, and the prymnesiophyte Prymnesium parvum (KAC 39, Kalmar Algal Collection) as the donor. Neither of the cultures was axenic, and both algae were isolated from the Baltic Sea, where Thalassiosira spp. usually precede $P$. parvum in annual succession (Edler 1979, Lindholm \& Virtanen 1992). Besides using species from the same environment, we chose these 2 species because it has been demonstrated that the algal allelopathic effect is usually more significant on groups preceding the allelopathic algae, since allelopathy can be used to achieve dominance over the predecessor group (Keating 1977, Fistarol et al. 2003).

\section{MATERIALS AND METHODS}

Algal cultures and growth conditions. Thalassiosira weissflogii cultures were grown in a basic $f / 10$ medium (Guillard 1975): all components, except nitrate and phosphate, were adjusted to $f / 10$ concentrations; nitrate and phosphate concentrations were adjusted to obtain nutrient limitation. The medium was made with filtered Baltic Sea water (GF/C glass microfiber filters), with salinity adjusted to $10 \mathrm{psu}$. The cultures were kept in a controlled culture room at $16^{\circ} \mathrm{C}, 100 \mu \mathrm{mol}$ photons $\mathrm{m}^{-2} \mathrm{~s}^{-1}$ and a $16: 8 \mathrm{~h}$ light:dark cycle. To obtain limitation by nitrate or phosphate, $T$. weissflogii was grown in semi-continuous cultures ( $500 \mathrm{ml}$ culture), and 3 sets (with 3 replicates each) with different nutrient condi- tions (N:P ratios) were made: (1) T. weissflogii diluted with medium at $\mathrm{N}: \mathrm{P}=16: 1\left(\mathrm{NO}_{3}{ }^{-}=116 \mu \mathrm{M}, \mathrm{PO}_{4}{ }^{3-}=\right.$ $7.2 \mu \mathrm{M})($ T. weissflogii NP); (2) T. weissflogii diluted with medium at $\mathrm{N}: \mathrm{P}=3.2: 1\left(\mathrm{NO}_{3}{ }^{-}=23.2 \mu \mathrm{M}, \mathrm{PO}_{4}{ }^{3-}=\right.$ $7.2 \mu \mathrm{M})$, which was considered to be nitrogen limited (T. weissflogii $-\mathrm{N}$ ); and (3) T. weissflogii diluted with medium at $\mathrm{N}: \mathrm{P}=80: 1\left(\mathrm{NO}_{3}{ }^{-}=116 \mu \mathrm{M}, \mathrm{PO}_{4}{ }^{3-}=1.45\right.$ $\mu \mathrm{M})$, which was considered to be phosphorus limited (T. weissflogii-P). These cultures were grown as batch cultures for $7 \mathrm{~d}$ prior to dilution procedures. Dilutions were made daily and lasted for $43 \mathrm{~d}$. The dilution rates used were chosen according to the growth rate of each treatment during the batch growth, as is indicated to establish a semi-continuous culture. Thus, T. weissflogii NP was diluted $35 \% \mathrm{~d}^{-1}$, T. weissflogii $-\mathrm{N}$ was diluted $16 \% \mathrm{~d}^{-1}$ and T. weissflogii-P was diluted $20 \%$ $\mathrm{d}^{-1}$.

The Thalassiosira weissflogii cultures were used in the experiment during steady-state growth (after Day 30) (Fig. 1), when T. weissflogii $-\mathrm{N}$ and $-\mathrm{P}$ were nitrogen and phosphorus limited, respectively, as shown by cellular nutrient contents and C:N, C:P and N:P ratios (Table 1). During the steady-state period, growth rates were calculated according to the steady-state growth rate calculations for semi-continuous cultures:

$$
\mu=\frac{\ln \left(\frac{V_{\text {tot }}}{V_{\text {tot }}-V_{\text {rep }}}\right)}{t}
$$

where $V_{\text {tot }}$ is the total culture volume, $V_{\text {rep }}$ is the volume replaced (volume of medium used in the dilutions) and $t$ is the time between dilutions. Thus, the growth rate $(\mu)$ during the steady-state period was $\mu=$ $0.43 \mathrm{~d}^{-1}$ for $T$. weissflogii NP, $\mu=0.17 \mathrm{~d}^{-1}$ for $T$. weissflogii $-\mathrm{N}$ and $\mu=0.22 \mathrm{~d}^{-1}$ for $T$. weissflogii $-\mathrm{P}$.

A semi-continuous culture of Prymnesium parvum was established in parallel to the Thalassiosira weissflogii

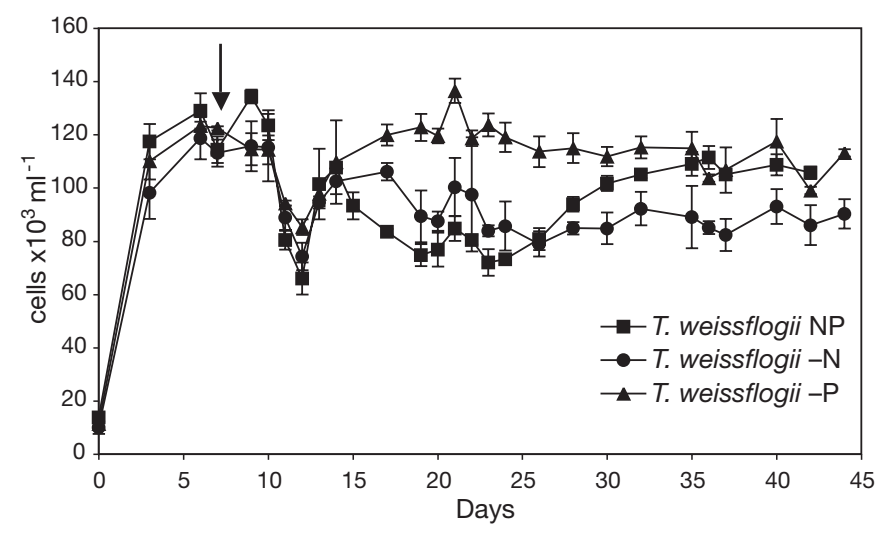

Fig. 1. Thalassiosira weissflogii. Growth curve of cultures grown with no nutrient limitation ( $T$. weissflogii NP), with $\mathrm{N}$ limitation ( $T$. weissflogii $-\mathrm{N}$ ) and with P limitation ( $T$. weissflogii $-\mathrm{P})$. Arrow indicates when the daily dilutions started 
Table 1. Cellular content (pg C/N/P cell ${ }^{-1}$ ) and molar ratios (C:N, C:P, and N:P) for the 3 Thalassiosira weissflogii treatments at the beginning (Day 31), and at the end (Day 43) of the steady state period $(\mathrm{n}=3$, mean $\pm \mathrm{SD}$ ). The cellular content (pg C/N/P cell $^{-1}$ ) and molar ratios (C:N, C:P, and N:P) for Prymnesium parvum culture during steady-state are also shown (Day 41)

\begin{tabular}{|c|c|c|c|c|c|c|}
\hline Treatment & pg C cell ${ }^{-1}$ & pg $\mathrm{N} \mathrm{cell}^{-1}$ & pg P cell ${ }^{-1}$ & $\mathrm{C}: \mathrm{N}$ & $\mathrm{C}: \mathrm{P}$ & $\mathrm{N}: \mathrm{P}$ \\
\hline \multicolumn{7}{|l|}{ Day 31} \\
\hline T. weissflogii NP & $52.9 \pm 4.3$ & $10.9 \pm 0.8$ & $2.2 \pm 0.01$ & 5.6 & 63.0 & 11.2 \\
\hline T. weissflogii-N & $55.3 \pm 5.7$ & $4.7 \pm 0.6$ & $1.6 \pm 0.2$ & 13.6 & 86.5 & 6.3 \\
\hline T. weissflogii-P & $50.5 \pm 6.5$ & $7.1 \pm 3.4$ & $0.5 \pm 0.2$ & 10.8 & 347.0 & 32.1 \\
\hline \multicolumn{7}{|l|}{ Day 43} \\
\hline T. weissflogii NP & $55.8 \pm 1.1$ & $11.5 \pm 0.2$ & $2.2 \pm 0.1$ & 5.7 & 65.0 & 11.5 \\
\hline T. weissflogii-N & $47.5 \pm 2.7$ & $5.8 \pm 0.5$ & $1.4 \pm 0.1$ & 9.6 & 89.1 & 9.3 \\
\hline T. weissflogii -P & $68.4 \pm 2.8$ & $10.4 \pm 0.2$ & $0.5 \pm 0.01$ & 7.7 & 353.9 & 46.1 \\
\hline \multicolumn{7}{|l|}{ Day 41} \\
\hline P. parvum & $28.6 \pm 1.1$ & $2.7 \pm 0.1$ & $0.4 \pm 0.1$ & 12.3 & 199.2 & 16.2 \\
\hline
\end{tabular}

cultures. This culture was maintained in $f / 10$ medium (Guillard 1975) with N:P = 16:1. The media used to dilute $P$. parvum culture had the same $\mathrm{NO}_{3}{ }^{-}$and $\mathrm{PO}_{4}{ }^{3-}$ concentrations as that used for dilution in the T. weissflogii NP treatment. The other components of the culture medium contained the concentrations of $f / 10$ medium (Guillard 1975). The cellular contents and the C:N, C:P and N:P ratios for P. parvum are shown in Table 1.

Experimental set-up. All experiments were performed by exposing Thalassiosira weissflogii to Prymnesium parvum cell-free filtrate. The filtrate was obtained by gentle filtration (a pressure lower than $-2 \mathrm{kPa}$ was used to create the initial vacuum for the filtration) of samples taken from the semi-continuous cultures of $P$. parvum through GF/F glass fiber filters. Two experiments were set, varying the frequency of filtrate additions.

Expt 1: We exposed Thalassiosira weissflogii grown under different nutrient conditions to a single addition of cell-free filtrate from Prymnesium parvum. In this test, the only factor varying was the nutrient state of $T$. weissflogii. The tests were performed in $21 \mathrm{ml}$ scintillation vials (total of 9 vials, 3 vials for each T. weissflogii treatment) containing a total of $20 \mathrm{ml}$ (12 ml were $P$. parvum cell-free filtrate, which corresponded to a culture that would contain $60 \times 10^{3}$ cells $\mathrm{ml}^{-1}$ of $P$. parvum, and $8 \mathrm{ml}$ were filled with aliquots from one of the T. weissflogii treatments, i.e. T. weissflogii NP, $-\mathrm{N}$, or $-\mathrm{P}$ ). The final concentration of $T$. weissflogii in the test tubes was $15 \times 10^{3}$ cells $\mathrm{ml}^{-1}$ (medium corresponding to the respective $T$. weissflogii treatment was added to complete the volume, if necessary). One control (in triplicate) was made for each T. weissflogii (NP, $-\mathrm{N},-\mathrm{P}$ ) treatment by adding, instead of filtrate, $12 \mathrm{ml}$ of $f / 10$ medium with the same nutrient concentration as that used to dilute the $P$. parvum NP culture. At the beginning of the experiment, the cell concentration of T. weissflogii in the test tubes was the same for all treatments and as in the controls. Aliquots $(2 \mathrm{ml})$ were sampled daily for direct cell counts (i.e. the samples were not fixed and were analyzed immediately). The experiment lasted $4 \mathrm{~d}$, and the allelopathic effect was observed by measuring differences in the cell numbers of the $T$. weissflogii treatments that received $P$. parvum filtrate compared to their respective controls (i.e. a control that was made by adding medium to a $T$. weissflogii culture that was grown under $\mathrm{NP},-\mathrm{N}$, or $-\mathrm{P}$ conditions); this eliminated the effect of nutrient limitation on growth, since the control was under the same growth conditions. Thus, any decrease in growth due to nutrient limitation was reflected in the control and discounted from the allelopathic effect.

Expt 2: We exposed Thalassiosira weissflogii to repeated additions of Prymnesium parvum cell-free filtrate. The first addition of filtrate and the experimental set-up were as described in Expt 1. After that, a new addition was made every day, over $4 \mathrm{~d}$, by removing $3 \mathrm{ml}$ of test volume, used for the cell counts, and replacing it with an equal volume of fresh filtrate or control medium.

Analytical procedures. Cell counts of non-fixed Thalassiosira weissflogii and Prymnesium parvum were made using a flow cytometer (FACScalibur, Becton Dickinson). Inorganic nutrients $\left(\mathrm{NO}_{3}{ }^{-}\right.$and $\left.\mathrm{PO}_{4}{ }^{3-}\right)$ were analyzed according to Valderrama (1995). Cellular contents $(C, N$, and $P$ ) were measured in cells retained on $25 \mathrm{~mm}$ pre-combusted $\left(450^{\circ} \mathrm{C}, 2 \mathrm{~h}\right) \mathrm{GF} / \mathrm{C}$ filters. The filters were dried overnight at $65^{\circ} \mathrm{C}$. Particulate organic carbon (POC) and particulate organic nitrogen (PON) were analyzed with a CHN elemental analyzer (FISONS Instruments, NA $1500 \mathrm{NC}$ ), and particulate organic phosphorus (POP) was analyzed following the method of Solórzano \& Sharp (1980). In addition, the $\mathrm{pH}$ values of $T$. weissflogii and $P$. parvum cultures were measured at the beginning and at the end of the steady state with a pH Meter 691 (Metrohm). 
Statistical analysis. Statistical analyses were performed using the software SPSS 10 for Macintosh. To verify if each Thalassiosira weissflogii treatment was affected by Prymnesium parvum NP filtrate, we compared the growth rate in the treatments that received filtrate with their respective controls (e.g. we compared the $3 T$. weissflogii $-\mathrm{P}$ that received $P$. parvum filtrate with the $3 T$. weissflogii-P that received control medium). The difference in the growth rate between each $T$. weissflogii treatment and its control was tested using a Student's $t$-test ( $\mathrm{n}=3$, for each treatment). We also compared $T$. weissflogii grown under different nutrient conditions (e.g. in Expt 1, we compared the response of the $3 T$. weissflogii treatments, NP, $-\mathrm{N}, \mathrm{P}$ ) to observe if there was a difference in sensitivity to allelochemicals. To assess the difference in sensitivity between the treatments, we performed 2 analyses: (1) testing differences in the growth rates of each treatment (which shows if the effect in one treatment was stronger than in the other) and (2) comparing the percentage of cells alive in each treatment (to observe if there was a difference and when the treatments started to differ). Both these tests were made using the GLM (general linear model) univariate analysis of SPSS, which corresponds to an ANOVA (analysis of variance). These analyses were made for both Expts 1 and 2 .

We used Student's t-test to compare growth rates of the corresponding Thalassiosira weissflogii treatments from Expts 1 and 2 (e.g. T. weissflogii NP single addition with $T$. weissflogii NP daily additions, and so on, to assess if there was a difference in the effect when adding the filtrate once or daily).

\section{RESULTS}

Thalassiosira weissflogii $-\mathrm{N}$ and $-\mathrm{P}$ semi-continuous cultures (Fig. 1) were N and P limited, respectively, as shown by the cellular nutrient contents and molar ratios (C:N, C:P and N:P) (Table 1). The $\mathrm{pH}$ values of T. weissflogii $(\mathrm{NP},-\mathrm{N}$ and $-\mathrm{P})$ and Prymnesium parvum cultures were approximately the same at the beginning and at the end of the steady state (Table 2), and they were higher in the $T$. weissflogii cultures $(\sim 9.3)$ than in the $P$. parvum cultures ( 8.2).

All 3 Thalassiosira weissflogii cultures (NP, $-\mathrm{N}$ and -P) were affected by a single addition of Prymnesium parvum filtrate (Fig. 2A). A single addition of P. parvum filtrate caused a decrease in the cell numbers of T. weissflogii $-\mathrm{N}$ and $-\mathrm{P} 1 \mathrm{~d}$ after exposure. However, by the second day, T. weissflogii $-\mathrm{N}$ and $-\mathrm{P}$ started to grow again, though less so than in the control. In addition, with the single filtrate addition, $T$. weissflogii NP retained positive growth, which was, however, lower
Table 2. $\mathrm{pH}$ in Thalassiosira weissflogii $(\mathrm{NP},-\mathrm{N}$, and -P) and Prymnesium parvum semi-continuous cultures at the beginning (Day 30) and at the end (Day 42) of the steady state $(\mathrm{n}=3$, mean $\pm \mathrm{SD})$

\begin{tabular}{|lcccc|}
\hline \multirow{2}{*}{ Treatment } & \multicolumn{2}{c}{ T. weissflogii } & \multicolumn{2}{c|}{ P. parvum } \\
& Day 30 & Day 42 & Day 30 & Day 42 \\
\hline NP & $9.2 \pm 0.1$ & $9.5 \pm 0$ & $8.2 \pm 0$ & $8.2 \pm 0$ \\
$-\mathrm{N}$ & $9.1 \pm 0.1$ & $9.1 \pm 0$ & - & - \\
$-\mathrm{P}$ & $9.4 \pm 0.1$ & $9.6 \pm 0$ & - & - \\
\hline
\end{tabular}

than in the control. All 3 treatments showed lower growth rates than their respective controls $(n=3$, mean \pm SD) - (1) T. weissflogii NP: filtrate treatment $\mu=0.38$ $\mathrm{d}^{-1} \pm 0.03$, control $\mu=0.52 \mathrm{~d}^{-1} \pm 0.02(t$-test, $\mathrm{p}=0.003)$; (2) $T$. weissflogii $-\mathrm{N}$ : filtrate treatment $\mu=0.19 \mathrm{~d}^{-1} \pm$ 0.02 , control $\mu=0.32 \mathrm{~d}^{-1} \pm 0.02$ ( $t$-test, $\left.\mathrm{p}=0.002\right)$; and (3) T. weissflogii -P: filtrate treatment $\mu=0.32 \mathrm{~d}^{-1} \pm$ 0.02 , control $\mu=0.44 \mathrm{~d}^{-1} \pm 0.01$ ( $t$-test, $\mathrm{p}=0.001$ ).

We compared the response between the 3 Thalassiosira weissflogii treatments that received a single filtrate addition to see if the nutrient state of $T$. weissflogii influenced its sensitivity to allelochemicals (Fig. 2B). T. weissflogii $-\mathrm{N}$ had a lower growth rate than the other 2 treatments (ANOVA, $T$. weissflogii $-\mathrm{N}$ $\neq T$. weissflogii $\mathrm{NP}, \mathrm{p}=0.0001 ; T$. weissflogii $-\mathrm{N} \neq T$. weissflogii $-\mathrm{P}, \mathrm{p}=0.002)$. $T$. weissflogii $-\mathrm{P}$ had a lower growth rate than $T$. weissflogii $\mathrm{NP}$, though the difference was only significant at the $90 \%$ level (ANOVA, $T$. weissflogii $-\mathrm{P} \neq T$. weissflogii $\mathrm{NP}, \mathrm{p}=0.056$ ). $\mathrm{By}$ looking at the percentage of cells in each filtrate treatment in relation to those in the respective control, we observed that $T$. weissflogii-N was more affected than the other 2 treatments (Fig. 2B). By Day 1, T. weissflogii $-\mathrm{N}$ already differed from the $T$. weissflogii NP treatment (ANOVA, $p=0.001$ ), by Day 2 it differed both from the $T$. weissflogii NP (ANOVA, $\mathrm{p}=0.008$ ) and from the $T$. weissflogii $-\mathrm{P}$ treatment (ANOVA, $\mathrm{p}=$ 0.006). However, thereafter, $T$. weissflogii cells started to recover: by Day $3 T$. weissflogii $-\mathrm{N}$ differed only from $T$. weissflogii-P (ANOVA, $\mathrm{p}=0.006$ ) and on Day 4 there was no difference between the treatments.

Repeated additions of Prymnesium parvum NP filtrate caused a decrease in the cell numbers of Thalassiosira weissflogii in all treatments (Fig. 3A-C). Furthermore, all treatments showed a negative growth rate, in contrast to Expt 1, where only a decrease in the growth rate was observed. The growth rates of the 3 filtrate treatments were significantly different from the positive growth of the controls $(\mathrm{n}=3$, mean $\pm \mathrm{SD})-$ (1) T. weissflogii NP: filtrate treatment $\mu=-0.08 \mathrm{~d}^{-1} \pm$ 0.04, control $\mu=0.37 \mathrm{~d}^{-1} \pm 0.01$ ( $t$-test, $\left.\mathrm{p}=0.0001\right)$; (2) $T$. weissflogii $-\mathrm{N}$ : filtrate treatment $\mu=-0.63 \mathrm{~d}^{-1} \pm 0.08$, control $\mu=0.20 \mathrm{~d}^{-1} \pm 0.02$ ( $t$-test, $\left.\mathrm{p}=0.0001\right)$; and (3) $T$. 
A
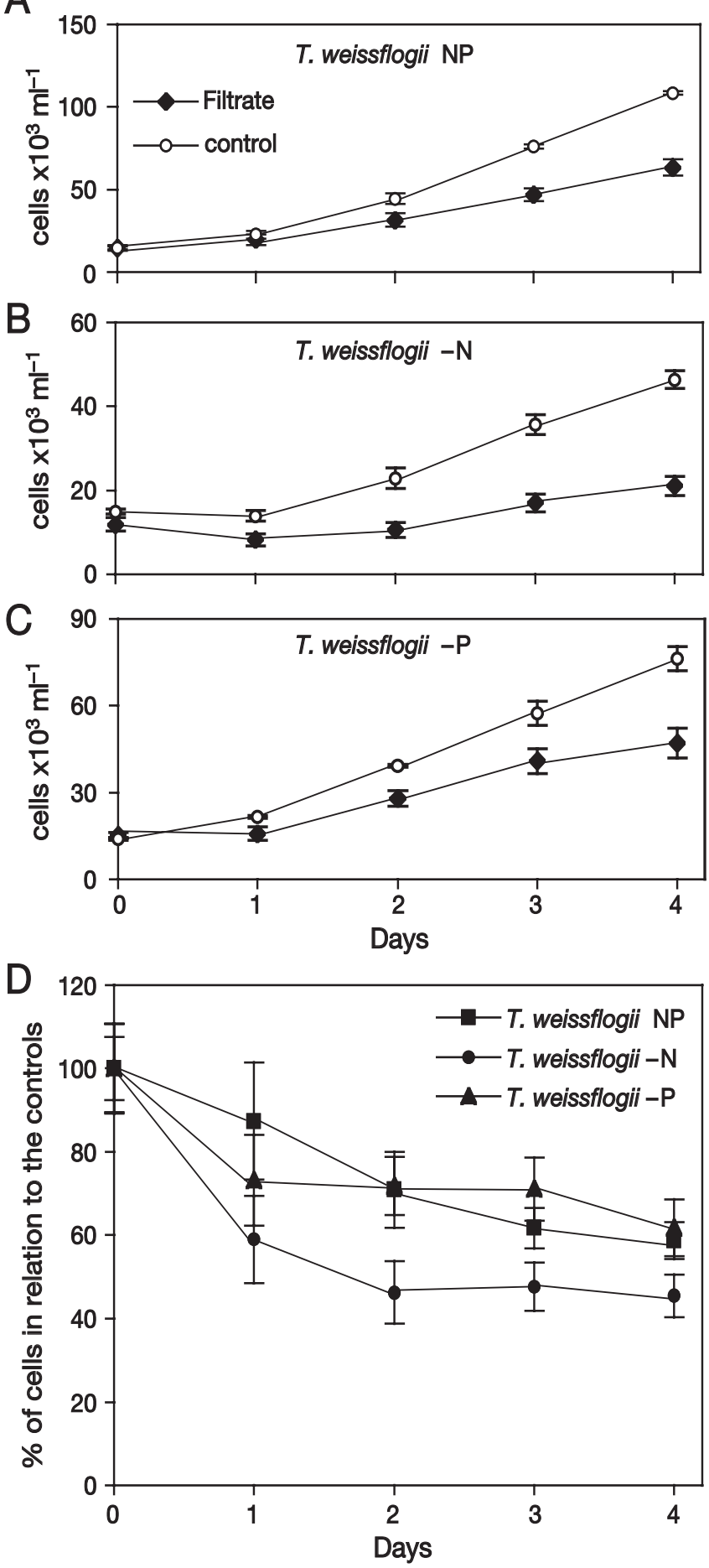

Fig. 2. Thalassiosira weissflogii. (A-C) Growth curves of $3 T$. weissflogii treatments when exposed to a single addition of Prymnesium parvum filtrate and of their respective controls (A: T. weissflogii NP + filtrate and $T$. weissflogii NP + control medium; B: T. weissflogii $-\mathrm{N}+$ filtrate and T. weissflogii $-\mathrm{N}+$ control medium; C: T. weissflogii $-\mathrm{P}+$ filtrate and T. weissflogii $-\mathrm{P}+$ control medium). (D) Comparison between the sensitivity of the $3 \mathrm{~T}$. weissflogii treatments, shown as percentage of cells in the filtrate treatment relative to the respective control $(\mathrm{n}=3$, mean $\pm \mathrm{SD})$
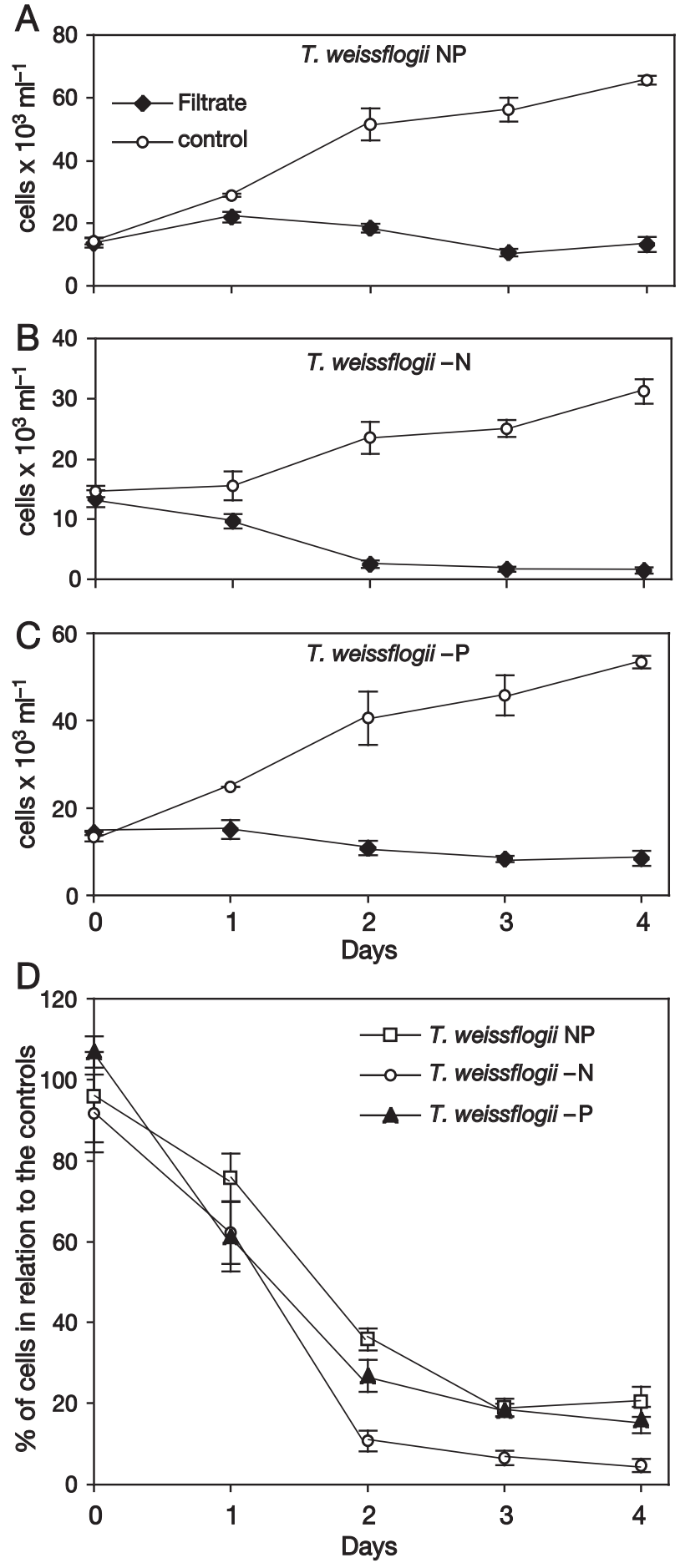

Fig. 3. Thalassiosira weissflogii. (A-C) Growth curves of $3 T$. weissflogii treatments when exposed to daily additions of Prymnesium parvum filtrate and of their respective controls (A: T. weissflogii NP + filtrate and T. weissflogii NP + control medium; B: T. weissflogii $-\mathrm{N}+$ filtrate and T. weissflogii $-\mathrm{N}+$ control medium; C: T. weissflogii $-\mathrm{P}+$ filtrate and T. weissflogii $-\mathrm{P}+$ control medium). (D) Comparison between the sensitivity of the $3 \mathrm{~T}$. weissflogii treatments, shown as percentage of cells in the filtrate treatment relative to the respective control $(\mathrm{n}=3$, mean $\pm \mathrm{SD})$ 
weissflogii -P: filtrate treatment $\mu=-0.17 \mathrm{~d}^{-1} \pm 0.04$, control $\mu=0.44 \mathrm{~d}^{-1} \pm 0.01$ ( $t$-test, $\mathrm{p}=0.01$ ) (Fig. 3A-C). T. weissflogii $-\mathrm{N}$ was again the most affected treatment, with a growth rate lower than that of the other 2 treatments (ANOVA, $T$. weissflogii $-\mathrm{N} \neq T$. weissflogii $\mathrm{NP}, \mathrm{p}=0.0001 ; T$. weissflogii $-\mathrm{N} \neq T$. weissflogii $-\mathrm{P}, \mathrm{p}=$ $0.0001)$. A difference in the percentage of cells between T. weissflogii -N and the other 2 treatments could already be observed on Day 1 (ANOVA, T. weissflogii-N $\neq T$. weissflogii NP, $\mathrm{p}=0.0001 ; T$. weissflogii $-\mathrm{N} \neq T$. weissflogii-P, $\mathrm{p}=0.004$ ), and this difference was maintained until the end of the experiment (ANOVA, $T$. weissflogii $-\mathrm{N} \neq T$. weissflogii $\mathrm{NP}, \mathrm{p}=0.0001 ; T$. weissflogii $-\mathrm{N} \neq T$. weissflogii $-\mathrm{P}, \mathrm{p}=0.0002)$. A significant difference between $T$. weissflogii-P and $T$. weissflogii NP could be observed on Days 1 and 2 (ANOVA, Day 1, $\mathrm{p}=0.0002$; Day $2, \mathrm{p}=0.00016)$. However, the daily additions of filtrate also caused a decrease in the T. weissflogii NP treatment, and by Day 3 there was no difference between $T$. weissflogii $-\mathrm{P}$ and $T$. weissflogii NP (ANOVA, $p=0.80$ ) (Fig. 3D).

When we compared the effect of a single addition of Prymnesium parvum filtrate with the effect of daily additions, we observed that all 3 Thalassiosira weissflogii were more affected by repeated filtrate additions than by a single addition of $P$. parvum NP filtrate (1 filtrate addition $\neq$ repeated filtrate additions, $t$-test, T. weissflogii NP, $\mathrm{p}=0.0001 ; T$. weissflogii $-\mathrm{N}, \mathrm{p}=$ 0.0001; T. weissflogii-P, $\mathrm{p}=0.0001$ ) (Fig. 4).

\section{DISCUSSION}

We showed that Thalassiosira weissflogii is affected by allelochemicals produced by Prymnesium parvum and that the effect varied depending on the nutrient state of $T$. weissflogii. T. weissflogii $-\mathrm{N}$ showed the highest sensitivity to allelochemical attack, T. weissflogii -P had an intermediate response and T. weissflogii NP was the most resistant. The role the donor organism plays in allelopathic interactions has already been investigated. $P$. parvum has been shown to affect both autotrophic and heterotrophic microorganisms in culture (Granéli \& Johansson 2003, Skovgaard \& Hansen 2003, Skovgaard et al. 2003, Tillmann 2003) and also natural plankton communities (Fistarol et al. 2003). However, in the present study, the results show the importance of the physiological state of the target organism in the outcome of the allelopathic interaction.

Plant competition interactions are usually explained by resource exploitation and allelopathy (Rice 1984). Both mechanisms can often occur simultaneously, and it is very difficult to separate the effect of resource exploitation from allelopathy in natural systems. It is important to evaluate the relative contribution of each

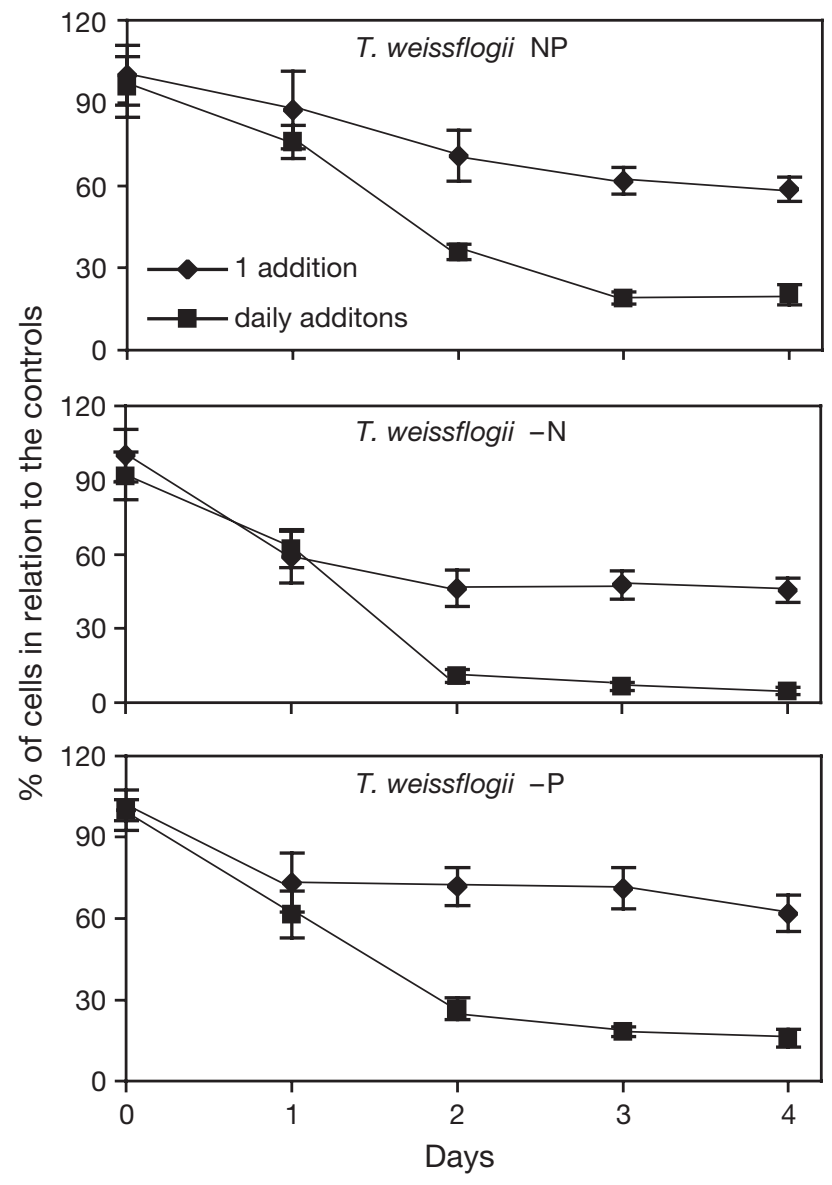

Fig. 4. Thalassiosira weissflogii. Comparison between the effect of a single addition and daily additions of Prymnesium parvum filtrate to each $T$. weissflogii treatment $(\mathrm{NP},-\mathrm{N},-\mathrm{P})$, expressed as percentage of cells in the filtrate treatment relative to the respective control $(n=3$, mean $\pm \mathrm{SD})$

mechanism during competitive interactions (Inderjit \& del Moral 1997). Furthermore, stress has been considered to be an important factor influencing allelopathic interactions. As pointed out by Inderjit \& del Moral (1997), it is unclear how stress reduces the importance of resource competition and makes allelopathy a major force structuring plant communities. One possibility is that stress increases the production of allelochemicals (Tang et al. 1995). In the present study, we demonstrated that nutrient stress also enhanced the impact of allelopathy on a microalgal species by increasing the sensitivity of the target organisms.

All our experiments were performed by exposing Thalassiosira weissflogii to Prymnesium parvum cellfree filtrate, ensuring that the affecting compounds had been excreted to the medium, which is necessary to characterize allelopathy (see Willis 1985). This procedure also excluded the effects of competition, which could occur if $P$. parvum cells were added to the $T$. weissflogii cultures, as well as the mixotrophic effect of 
P. parvum. Both donor and target species were ecologically relevant, since they were isolated from the same environment and were at cell concentration levels realistic in nature (blooms of $P$. parvum can reach con-

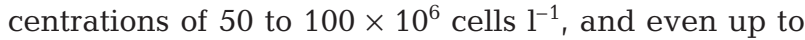
$10^{9}$ cells ${ }^{-1}$; Edvardsen \& Paasche 1998). $\mathrm{pH}$ is also a factor that can influence the outcome of allelopathic interactions. It has been shown that the allelopathic effect of Chrysochromulina polylepis on Heterocapsa triquetra increases if the $\mathrm{pH}$ is raised, with the highest effect being observed at a pH between 8 and 9, depending on the cell concentration of $C$. polylepis (Schmidt \& Hansen 2001). In our experiment, the $\mathrm{pH}$ in $P$. parvum cultures was lower than that in $T$. weissflogii cultures; therefore, we argue that the $\mathrm{pH}$ did not increase the allelopathic effects. The algal cultures used in our experiment were not axenic. Bacteria could influence allelopathy by degrading allelochemicals or by metabolizing them into new compounds. The first case would decrease the allelopathic effect, while the latter could either increase or decrease it, depending on the activity of the new compound. Bacteria may also produce their own allelochemicals. However, some studies (Tillmann \& John 2002, Suikkanen et al. 2004) seem to indicate that bacteria present in algal cultures are not responsible for the allelopathic effect of the microalgae. Because bacteria may interfere in the allelopathic effect, their presence represents a more natural situation (Maestrini \& Bonin 1981). Nevertheless, since the removal of bacteria from the filtrates used to test allelopathy did not change the effect (Suikkanen et al. 2004), the role of bacteria may be minor.

\section{Effect of nutrient limitation and enhancement of the allelopathic effect}

Both nitrogen and phosphorus limitation occur in the Baltic Sea (nitrogen is usually the limiting nutrient in coastal areas of the Baltic proper; phosphorus can be found limiting production during spring and summer) (Granéli et al. 1990). Unbalanced nutrient conditions are a problem in several coastal areas due to eutrophication (Paerl 1995, Skei et al. 2000). Thus, it is important to understand how nutrient limitation will affect species interactions. The resultant allelopathic effect of Prymnesium parvum on Thalassiosira weissflogii was enhanced by having the target algae limited by nutrients. Both nitrogen and phosphorous limitation increased the sensitivity of $T$. weissflogii to allelochemicals, though nitrogen limitation had a stronger influence. This indicates that allelopathy, and consequently resource competition, is affected, not only by nutrient limitation in general, but also according to the limiting nutrient.
Though some studies indicate that nutrient limitation can increase the toxicity of Prymnesium parvum (Granéli \& Johansson 2003, Barreiro et al. 2005), it has not yet been tested if toxin production would decrease if nutrients were added to a limited $P$. parvum culture. It has also not been tested if addition of nutrients would alleviate the sensitivity of a nutrient-limited target. We hypothesize that, given enough time for the target to recover, i.e. the cells would have sufficient time to incorporate the nutrient added before being killed by the allelochemicals, the nutrient-replete cells would probably show a lower sensitivity, similar to that in the Thalassiosira weissflogii NP treatment.

Although it has been proposed that stress increases the sensitivity of target organisms to allelochemicals (Einhellig 1996, Reigosa et al. 1999), the biochemical mechanisms that cause this increase have not been demonstrated. However, the general physiological responses of plants and microorganisms to nutrient limitation are the accumulation of carbon in the cells, first as carbohydrate and then as lipid, while protein/ amino acid cellular contents decrease as does cell division (Healey 1973). Due to the extremely important roles that proteins (including enzymes) play in regulating all cell functions, it is understandable that a decrease in protein content would affect cell resistance. To affect the physiology of a target cell, allelochemicals need to penetrate the cell membrane, which acts as a barrier against toxic compounds. Since cell membranes are formed by a thin film of a lipid bilayer and protein molecules, held together mainly by non-covalent interactions (Alberts et al. 1994), changes in the protein and lipid concentrations and in their production are bound to have consequences for the plasma membrane. Furthermore, proteins are responsible for most membrane functions, e.g. transporting specific molecules, or catalyzing reactions such as ATP synthesis (Alberts et al. 1994). Thus, if there is a decrease in the protein content of the cell due to nutrient limitation, it will not only have a structural effect on the membrane, but many functions will also be compromised.

An example of the effect of nutrient limitation on the membrane is given by Ferenci (1999) and Liu \& Ferenci (2001). They showed that bacteria respond to nutrient limitation by altering membrane permeability. Limitation elicits a complex gene regulation system that makes the membrane more permeable to nutrients, e.g. glucose. If nutrient stress were to trigger this kind of response in algae so that they can increase nutrient uptake, it would, in fact, cause a disadvantage if the algae were also under allelochemical attack.

Thus, $\mathrm{N}$ and P limitation of Thalassiosira weissflogii might have caused an increase in the sensitivity of this alga by increasing membrane permeability and also by reducing protein, nucleic acids and phospholipids, 
which may compromise the physiology of the cell, membrane functions and structure.

Besides the physiological state of the target algae, daily additions of filtrate also enhanced the allelopathic effect of Prymnesium parvum on Thalassiosira weissflogii. Allelochemicals seem to have a short lifespan, as shown in our study by the recovery of organisms exposed to a single addition of filtrate some time after exposure. T. weissflogii $-\mathrm{P}$, which had an intermediate response, showed some resistance when exposed to a single addition of $P$. parvum filtrate, but it was not resistant when continuously exposed to filtrate. When the exposure to allelochemicals was prolonged, not even $T$. weissflogii NP survived; it was not only inhibited, but also killed by the filtrate, as was T. weissflogii $-\mathrm{N}$ and $-\mathrm{P}$. Allelochemicals may be removed from the system by degradation (e.g. by light reactions or bacteria degradation), as occurs for some microalgal toxins (Reich \& Parnas 1962, Christoffersen et al. 2002), or by, for example, binding to cell membranes (Tillmann 2003). Nevertheless, in nature, allelochemicals are probably constantly released from the donor species. Thus, applying repeated filtrate additions better mimics natural environmental conditions.

\section{Consequences for the outcome of allelopathic interactions}

It has been shown that some microalgae can cause allelopathy under non-limiting nutrient conditions (Arzul et al. 1999, Schmidt \& Hansen 2001, Tillmann \& John 2002, Fistarol et al. 2003, 2004, Suikkanen et al. 2004). This means that it is not only a strategy used under nutrient-limited conditions. However, the allelopathic effect may be enhanced under certain conditions. Under limiting nutrient conditions, the allelopathic effect is higher due to the increased sensitivity of the target. The allelopathic effect is also higher when the allelochemicals are continuously released by the donor, as occurs under natural conditions. In these situations, the competitive balance turns towards the allelopathic species. Reigosa et al. (2002) proposed that allelopathy would only become important in special situations, when plants are under stress, i.e. the stress hypothesis. Thus, nutrient limitation may be an example of when allelopathy becomes more important than resource competition in competitive interactions.

In conclusion, our work has shown that under nutrient limitation allelopathic interactions can play a major role in phytoplankton competition, especially if we consider that in natural environments allelochemicals are continuously released. Further studies should try to reveal the exact biochemical pathway that renders the target algae more sensitive when nutrient limited.
Acknowledgements. We thank C. Esplund-Lindquist and G. Wannhoff for help with the nutrient analyses. We also thank U. Tillmann and P. S. Salomon for the constructive review of this manuscript. Financial support was provided by the Brazilian National Research Council (CNPq) (PhD grant to G.O.F., Contract 200384/00-7), by the European Commission through the BIOHAB and FATE projects (EC Grants EVK3-CT9900015 and EVK3-2001-00055) as part of the EC-IMPACTEUROHAB cluster.

\section{LITERATURE CITED}

Alberts B, Bray D, Lewis J, Raff M, Roberts K, Watson JD (1994) Molecular biology of the cell, 3rd edn. Garland Publishing, New York

Arzul G, Seguel M, Guzman L, Denn EE (1999) Comparison of allelopathic properties in three toxic Alexandrium species. J Exp Mar Biol Ecol 232:285-295

Barreiro A, Guisande C, Maneiro I, Lien TP and 5 others (2005) Relative importance of the different negative effects of the toxic haptophyte Prymnesium parvum on Rhodomonas salina and Brachionus plicatilis. Aquat Microb Ecol 38:259-267

Christoffersen K, Lyck S, Winding A (2002) Microbial activity and bacterial community structure during degradation of microcystins. Aquat Microb Ecol 27:125-136

Edler L (1979) Phytoplankton succession in the Baltic Sea. Acta Bot Fenn 110:75-78

Edvardsen B, Paasche E (1998) Bloom dynamics and physiology of Prymnesium and Chrysochromulina. In: Anderson DM, Cembella AD, Hallegraeff GM (eds) Physiological ecology of harmful algal blooms. NATO ASI Ser G Ecol Sci 41:193-208

Einhellig FA (1995) Allelopathy: current status and future goals. In: Inderjit, Dakshini KMM, Einhellig FA (eds) Allelopathy: organisms, processes and applications. ACS Symp Ser 582:1-24

Einhellig FA (1996) Interactions involving allelopathy in cropping systems. Agron J 88:886-893

Ferenci T (1999) Regulation by nutrient limitation. Curr Opin Microbiol 2:208-213

Fistarol GO, Legrand C, Granéli E (2003) Allelopathic effect of Prymnesium parvum on a natural plankton community. Mar Ecol Prog Ser 255:115-125

Fistarol GO, Legrand C, Selander E, Hummert C, Stolte W, Granéli E (2004) Allelopathy in Alexandrium spp.: effect on a natural plankton community and on algal monocultures. Aquat Microb Ecol 35:45-56

Granéli E, Johansson N (2003) Increase in the production of allelopathic substances by Prymnesium parvum cells grown under N- or P-deficient conditions. Harmful Algae 2:135-145

Granéli E, Wallström K, Larsson U, Granéli W, Elmgren R (1990) Nutrient limitation of primary production in the Baltic Sea Area. AMBIO 19:142-151

Guillard RR (1975) Culture of phytoplankton for feeding marine invertebrates. In: Smith WL, Chanley MH (eds) Culture of marine invertebrate animals. Plenum Press, New York, p 29-60

Healey FP (1973) Inorganic nutrient uptake and deficiency in algae. Crit Rev Microbiol 3:69-113

Inderjit, del Moral R (1997) Is separating resource competition from allelopathy realistic? Bot Rev 63:221-230

Keating KI (1977) Allelopathic influence on blue-green bloom sequence in a eutrophic lake. Science 196:885-886

Legrand C, Rengefors K, Fistarol GO, Granéli E (2003) 
Allelopathy in phytoplankton-biochemical, ecological and evolutionary aspects. Phycologia 42:406-419

Lindholm T, Virtanen T (1992) Bloom of Prymnesium parvum Carter in a small coastal inlet in Dragsfjärd, southwestern Finland. Environ Toxicol Water Qual 7:165-170

Liu X, Ferenci T (2001) An analysis of multifactorial influences on the transcriptional control of $o m p F$ and $o m p C$ porin expression under nutrient limitation. Microbiology 147:2981-2989

Maestrini SY, Bonin DJ (1981) Allelopathic relationships between phytoplankton species. In: Platt T (ed) Physiological bases of phytoplankton ecology. Can Bull Fish Aquat Sci 210:323-338

Paerl HW (1995) Coastal eutrophication in relation to atmospheric nitrogen deposition - current perspectives. Ophelia 41:237-259

Reich K, Parnas I (1962) Effect of illumination on ichthyotoxin in an axenic culture of Prymnesium parvum Carter. J Protozool 9:38-40

Reigosa MJ, Sánchez-Moreiras A, González L (1999) Ecophysiological approach in allelopathy. Crit Rev Plant Sci 18:577-608

Reigosa MJ, Pedrol N, Sánchez-Moreiras AM, González L (2002) Stress and allelopathy. In: Reigosa MJ, Pedrol N (eds) Allelopathy, from molecules to ecosystems. Science Publishers, Enfield, CT, p 231-256

Rice EL (1984) Allelopathy. Academic Press, New York

Rizvi SJH, Haque H, Singh VK, Rizvi V (1992) A discipline called allelopathy. In: Rizvi SJH, Rizvi V (eds) Allelopathy: basic and applied aspects. Chapman \& Hall, London, p 1-19

Schmidt LE, Hansen PJ (2001) Allelopathy in the prymnesiophyte Chrysochromulina polylepis: effect of cell concen-

Editorial responsibility: Paul J. Harrison,

Kowloon, Hong Kong SAR tration, growth phase and pH. Mar Ecol Prog Ser 216: $67-81$

Skei J, Larsson P, Rosenberg R, Jonsson P, Olsson M, Broman D (2000) Eutrophication and contaminants in aquatic ecosystems. AMBIO 29:184-194

Skovgaard A, Hansen PJ (2003) Food uptake in the harmful Prymnesium parvum mediated by excreted toxins. Limnol Oceanogr 48:1161-1166

Skovgaard A, Legrand C, Hansen PJ, Granéli E (2003) Effects of nutrient limitation on food uptake in the toxic haptophyte Prymnesium parvum. Aquat Microb Ecol 31:259-265

Solórzano L, Sharp JH (1980) Determination of total dissolved phosphorus and particulated phosphorus in natural waters. Limnol Oceanogr 25:754-758

Suikkanen S, Fistarol GO, Granéli E (2004) Allelopathic effects of the Baltic cyanobacteria Nodularia spumigena, Aphanizomenon flos-aquae and Anabaena lemmermannii on algal monocultures. J Exp Mar Biol Ecol 308:85-101

Tang CS, Cai WF, Kohl K, Nishimoto RK (1995) Plant stress and allelopathy. J Am Chem Soc 582:142-157

Tillmann U (2003) Kill and eat your predator: a winning strategy of the planktonic flagellate Prymnesium parvum. Aquat Microb Ecol 32:73-84

Tillmann U, John U (2002) Toxic effects of Alexandrium spp. on heterotrophic dinoflagellates: an allelochemical defence mechanism independent of PSP-toxin content. Mar Ecol Prog Ser 230:47-58

Valderrama JC (1995) Methods of nutrient analysis. In: Hallegraeff GM, Anderson DM, Cembella AD (eds) Manual of harmful marine microalgae. IOC Guides No. 33, UNESCO, Paris, p 251-268

Willis RJ (1985) The historical bases of the concept of allelopathy. J Hist Biol 18:71-102

Submitted: August 12, 2004; Accepted: September 15, 2005

Proofs received from author(s): November 22, 2005 